\title{
The relationship between ILL/document supply and journal subscriptions
}

\author{
Elena Bernardini, Silvana Mangiaracina
}

\begin{abstract}
Purpose: The purpose of this article is to provide insights into the relationship between ILL/ document supply and journal subscriptions and to assess recent trends in the ILL service.

Design/methodology/Approach: This survey is based on data from the ILL service conducted over the five year period 2005-2009 through the Italian NILDE (Network for Inter-Library Document Exchange) network.

Findings: This article bears out important previous findings that ILL is not used as a surrogate for journal subscriptions. This is supported by the analysis of a broad number of titles and over a wide time-range. On the contrary, analysis of data transactions, particularly of the most requested journals, can bring about positive effects on new title acquisitions and negotiations with publishers. This paper also shows, at least for Italy, an overall growth and vitality of ILL, in spite of the widespread availability of e-journals acquired through consortia purchasing.

Originality/Value: An insight into the relationship between ILL and journal subscriptions in Italy, a country where few studies have been carried out, and none at all for such a large number of libraries and transactions.
\end{abstract}

Keywords: interlibrary loan, ILL, resource sharing, document supply, electronic journals, consortia purchasing, Italy

Paper type: Research paper

\section{Introduction}

The relationship between the Inter Library Loan service (ILL) and journal subscriptions is a recurring issue in recent literature. Does ILL affect electronic or print journal subscriptions? Vice versa, do electronic journal subscriptions affect ILL?

This study, based on an analysis of the nationwide ILL service in Italy (the authors will use ILL to refer to the supply of copies of journal articles and other non-returnable materials), examines the relationship between ILL and journal subscriptions. The Italian survey presented not only confirms important previous results, but also casts new light on these issues.

To investigate the nature of the relationship between ILL and journal subscriptions in the digital era, it is useful to see the service in the context of copyright law. This matter has been well described by Simonetta Vezzoso: "The Inter Library Loan service has a long and commendable history based on the idea that documents should be accessible to a patron independent from the latter's location. However when ILL started developing into the supply of a surrogate copy (photocopy) of the requested document, it met fierce opposition from publishers, who were fearing substantial loss of their revenue. The introduction of electronic document supply greatly increased these concerns, in particular with regard to articles published in scientific and technical journals. In fact, publishers consider that the possibility of patrons obtaining copies of articles at almost the same speed as if they were available by subscription to an e-journal would give libraries even more reason to cancel subscriptions thus affecting the normal exploitations of works and the legitimate interests of rights holders." (Vezzoso, 2006).

On the other hand, libraries want to be able to offer an ILL service that meets their patrons increased information needs and expectations of quick delivery of the requested materials. Thanks to the new integrated platforms based on the OpenURL standard (NISO, 2005), such as SFX journal citation link resolver and similar systems, high level integration at the user-interface has been reached for many library resources and services: library catalogs, bibliographical databases, full- 
text journals, document supply and other available electronic resource. There is no reason why the ILL service must remain anchored to the past, not benefitting from the technology improvements.

Electronic ILL involves complex copyright issues, many of which have been raised in a case involving Subito, the German library document supply service, (Vezzoso, 2006). In particular, the compliance of electronic ILL services with the Directive 2001/29/EC on the harmonization of certain aspects of copyright and related rights (SocInfo Directive) was questioned by publishers, fearing economic damage to journal subscriptions caused by ILL.

However, the ILL activity carried out by libraries, even with "point-to-point" electronic transmission of the "graphic document", does not appear to conflict with the SocInfo Directive's article 5 (limitations and exceptions), (Vezzoso, 2005). Besides, overcoming the "three-step test" barriers ${ }^{1}$, requires verification of the link between ILL and the loss of income to publishers. Such an evaluation should not be driven by preconceptions or the fear of loss of income. It should be considered not only for present but also future potential loss of income deriving not only from cancellations of current subscriptions, but also from the loss of new titles subscriptions.

\section{Literature Review}

Several important studies have been carried out in libraries on the impact of document delivery and ILL on journal subscriptions. All of them conclude that ILL does not affect subscriptions. For example, Woodward, finds that "the prime motivation in forcing cancellations are user interests and financial pressures; alternative access to the journal by the replacement of subscriptions with borrowing is marginally important", (Woodward, 1978). Later, Russon concludes that "ILL is not used as an alternative to subscriptions; ... the majority of ILL use is from institutions which have only occasionally need to consult a journal" (Russon and Campbell, 1996). Another survey sponsored by The International Council for Scientific and Technical Information, reached similar findings: "Publishers need not worry that institutions are using document supply as a realistic alternative to subscribing to journals. None of the organizations surveyed came anywhere near the break-even point at which it would be more economic to subscribe to a journal rather than use document supply for the few requests for articles made”, (ICSTI, 1996). A wider study reported both by Russon and Murdoch, carried out at the British Library in cooperation with 15 publishers and the Canada Institute for Scientific and Technical Information, concludes that "There is a real need from a large number of organizations for article supply.... Apart from a handful of instances, it doesn't seem plausible to argue that document supply is having any discernible effect on subscriptions”, (Russon, 2001), (Murdoch, 2001). A study at Illinois University and state libraries during 1996/1997, found that the highest average number of requests per title did not exceed the Copyright Guidelines CONTU ${ }^{2}$ "rule of five". They found that: "While there are probably some individual titles generating more requests than the rule of five, it is reassuring to see that overall, the average is within copyright guidelines". In a follow-up study they confirmed that "libraries continue to operate well within the copyright guidelines set by CONTU”, (Wiley and Chrzastowski, 2001), (Wiley and Chrzastowski, 2005).

When we consider the reverse situation - that of the impact on ILL of e-subscriptions, we have to consider the great impact of the new consortia deals which publishers and libraries have adopted since the late $1990 \mathrm{~s}$, resulting in an enormous increase in e-journal availability. A number of studies

\footnotetext{
1 The three-step test - by which limitations on exclusive copyrights are confined to 'certain special cases' which do not conflict with a 'normal exploitation of the work' and do not 'unreasonably prejudice the legitimate interests of the author'- is among the most enduring of standards affecting limitations on intellectual property rights. See (Senftleben, 2004).

2 The CONTU guidelines on generally accepted document delivery practices were negotiated in the seventies between publishers and libraries by the National Commission on New Technological Uses of Copyrighted Works in the USA.
} 
have suggested a link between the adoption of Big Deals and the decline in document supply in many countries - see for example, (Line et al. 2002), (Kidd, 2003).

Research from Spain, (Echeverria and Barredo, 2005) reported statistical data for document supply in Spanish university libraries, showing a 17\% decrease between 2000 and 2002. Document supply in French university libraries showed a 27\% decline between 2000 and 2002, (Gillet, 2008), and concluded that, "In general, the use of document delivery in university libraries has decreased since the introduction of a critical mass of online journals from 2000 onwards." Research from Illinois reported a decline of nearly $26 \%$ from 1999 to 2003 in the number of ILL requests, (Wiley and Chrzastowski, 2005). An analysis, between 2003 and 2007, found a significant drop of 37\% in document supply activity at the National Health Service North West libraries in the UK, (Glover et al., 2007). Data analysis of over 2.2 million ILL requests in the National Library of Medicine's DOCLINE system from 3,234 US and Canadian medical libraries found that, despite the 24-fold increase in searching the medical literature via PubMed, the total number of ILL requests increased by only $22.5 \%$ to its peak in 2002 and has declined since then to nearly the 1992 level, (since the 2002 peak, decline has been between 6\% and 9\% each year), (Lacroix and Collins, 2007). In contrast, the Association of Research Libraries (ARL) study on Assessing ILL/DD services (Jackson, 2004), showed that ILL continued to grow even with the widespread introduction of big deals, so that the increase of the number of electronic journals available does not always lead to the reduction in ILL requests. The increasing trend is still true, as can be seen in the 2004-2009 statistical usage data published on the ARL website [1].

An interesting result was found in the Japanese university context, where an apparently stable and slow increase in the total number of requests from 1994 to 2007, actually hid a significant change in researchers' information requirements. Requests for photocopies of foreign journal articles increased until the late 1990s and then, from 1999, they began to steadily decrease, caused by the advent of Big Deal consortial agreements involving those foreign journals, the requests for domestic journal articles grew and eventually exceeded those for foreign journals, (Tutiya et al., 2007), (Koyama et al., 2009).

To sum up, there is no clear trend found in the literature and the impact on ILL of e-subscriptions, especially on Big Deal consortia purchases, has not yet been fully assessed.

In this study we investigate ILL activity in Italy through the NILDE (Network for Inter-Library Document Exchange) network over the five-year period 2005-2009. The data relate to more than 600 Italian libraries belonging to university, public research institutions, health research institutions, hospitals and not-for-profit organizations using ILL on a reciprocal basis. Within the NILDE network every library acts both as a provider and a borrower.

The results obtained from our study show that ILL undoubtedly is not being used as a surrogate to journal subscriptions. On the contrary, analysis of ILL data transactions could bring about positive effects on new contracts and negotiations with publishers. A knowledge of the most requested serial titles via ILL may provide to both library collection and consortia managers very useful insights to help guide electronic journal acquisitions including the evaluation of new consortia purchasing of the most requested titles via ILL.

Many previous studies, with the exception of ARL, show that ILL demand has declined after the advent of Big Deal contracts. Most of them compare ILL requests data before and after the adoption of Big Deals (this happened in almost all countries, including Italy, between 1999 and 2002, when contracts with big publishers such as Elsevier, Kluwer and Springer were signed).

The NILDE data used in the present study relate to a period of the "consolidated" Big Deal era. Since the NILDE network of libraries was established during 2004, there are no data to compare before or after the advent of Big Deal contracts in Italy. We may assume, on the basis of communications with libraries, representative in size and subject, - for example, (Mangiaracina and Beghelli, 2004) - that the access to Big Deal e-journals has led to a fall in requests between 2001 and 2003. The aim of this paper is not to compare our data with the pre-Big Deal era of ILL, but to 
assess recent trends in the ILL service. The results obtained show an overall growth and vitality of ILL, in spite of the great availability of e-journals acquired through consortia purchasing.

\section{The NILDE system and network of libraries}

The NILDE system was initially developed at the Italian National Research Council's (CNR) Bologna Research Area Library with the aim of improving ILL services based on Internet technologies and to promote cooperation between the CNR and Italian university libraries, (Mangiaracina, 2002).

The initial vision for NILDE was:

- to create web-based ILL-manager software to computerize the entire ILL workflow activity and to allow secure electronic transmission of documents;

- $\quad$ to promote a cooperative model based on quality of service, which libraries might pursue on a national, regional or disciplinary affinity basis;

- $\quad$ to initiate a virtuous interactive cycle in Italy: if each library had the chance to measure its lending turnaround time it could be compared with the performance of other participants. It has been shown, (Mangiaracina et al., 2008) that this stimulates libraries to improve their service. As a consequence, not only will the requesting libraries benefit but, eventually, so will the overall system and the end-users.

These initial expectations have now been met and have led librarians to see NILDE as an essential daily working tool, used currently by 728 libraries: $75 \%$ are university libraries, $10 \%$ are health research institutes and hospitals, $6 \%$ are public research institutions, and $9 \%$ are other public and not-for-profit organizations.

The NILDE software was developed in 2000 in an Open Source Software environment, using Linux O.S., Apache Web server, MySQL and PHP. The 4.0 software release adds the use of cutting edge web technologies, usually referred to as Web 2.0 and includes MySQL 5, PHP 5, XHTML 1.0, CSS2, Ajax. New features and innovative user-interaction styles are introduced in order to make NILDE an even more user-oriented and friendly tool for ILL and scholarly work, (Mangiaracina et al., 2008).

NILDE's present features comprise:

- $\quad$ a suite of ILL manager software modules which support borrowing and lending among libraries, including a statistical package which generates ILL performance indicators, such as fill rate and turn-around time;

- an electronic transmission module providing Secure Electronic delivery by uploading files to a web server. Pdf files are "hard-copied", that is, automatically converted to graphic files, in order to comply with ILL clauses in electronic licenses that usually do not allow the sending of the publisher's original Pdf file, but only of a printed copy, (Zaetta and Mangiaracina, 2008);

- Z.39.50 implementation to search the Italian Catalogues within the NILDE (borrowing) environment;

- a dedicated end-user module to manage personal bibliographical references, allowing users to easily import, organize and export references, and to initiate an ILL request when the document is not directly accessible (from any bibliographic database, via Open-URL);

- federated end-user authentication via Shibboleth;

- a software-like user interface, Web 2.0 style, and a fully customizable environment;

- $\quad$ multilingual support;

- $\quad$ compliance with W3C guidelines for accessible and usable web development. 
Since 2004, in order to join NILDE [2], each library must subscribe to the NILDE Rules and Regulations [3], agreeing to:

a) reciprocally supply documents;

b) facilitate access to its holdings, through joining at least one Italian common catalogues or meta-catalogues;

c) supply documents as soon as possible;

d) supply documents at no charge and, in the case of high usage, request a one-off payment at the end of the year;

e) distribute its requests equally between all libraries.

All libraries are required by the NILDE Rules and Regulations to comply with Italian copyright law and, where applicable, the permitted uses of ILL according to specific electronic licenses.

Unless licenses explicitly allow the electronic delivery of documents, either as a Pdf file or a scanned printed copy, libraries agree to supply patrons only with a printed copy of the document, even if the library possesses a digital copy.

Thanks to the rapid and ongoing growth in membership, the evolution of NILDE has shown just how urgent the need was in Italy for the adoption of standardized and structured processes for ILL services by implementing best practices in resource sharing.

It should be noted that although NILDE is the most popular and widespread system employed for ILL requests (of copies of articles and other non-returnables) in Italy, libraries may also use other systems, therefore, this study does not cover all requests.

\section{Methodology}

ILL transactions analysis is an important instrument for monitoring the network's performance and underpins the decisions and future strategies of library managers. A preliminary study, (Filippucci et al., 2009) focused on two important aspects: firstly an analysis of NILDE network performance in terms of turnaround time, reciprocity factor and requested/supplied documents imbalance, and secondly an analysis of the most ILL requested serial titles and their relationship to consortia e-only acquisitions. In this paper we present more insights on the latter issue taken from our study described below.

Data on filled and unfilled ILL requests from 2005 to 2009 were extracted from the NILDE online database and stored in a new local "warehouse" a MySQL database called Whnilde. Library identities in the Whnilde database are anonymous.

Unfortunately, bibliographic metadata associated with ILL transactions, particularly journal titles, are neither complete nor available in a standard format. Total filled requests within the five-year period were 491,414 and referred to 49,886 apparently unique titles. Actually, many titles appeared in different versions and it was necessary to identify each unique title for statistical analysis. Table 1 is an example of diversity in title forms encountered. Heterogeneity has several causes, as the request form can be completed in many different ways. Even a blank space could cause a duplication of the same title. Variations may occur due to:

- $\quad$ the request originating from catalogues using different rules for title cataloguing

- the NILDE software is OpenURL-compliant: the references derive from databases such as Pubmed, ISI Web of Science or Scifinder Scholar using different standards for titles (i.e., full or abbreviated title)

- manual input with spelling mistakes or non-standard title abbreviations 


\begin{tabular}{|l|}
\hline *Journal of agricultural and food chemistry \\
\hline *Journal of agricultural and food chemistry (Online) \\
\hline J Agr. Food Chemistry \\
\hline J Agric Food Chem \\
\hline J Agric Food Chem DEP VET VIII B \\
\hline J Agric Food Chem. \\
\hline J. Agric. Food Chem \\
\hline J. Agric. Food Chem. \\
\hline j. agric. food chemistry \\
\hline J. agric.Food Chem \\
\hline J.Agric. Food Chem. \\
\hline J.Agric.food chem. \\
\hline Journal Agricultural and food chemistry \\
\hline Journal Agricultural Food Chemistry \\
\hline Journal Agricultural Food Chemistry. \\
\hline Journal of Agricultural and Food Chemistry \\
\hline Journal of Agricultural \& Food Chemistry \\
\hline Journal of Agricultural and Food Chemistry \\
\hline Journal of Agricultural and Food Chemistry. \\
\hline journal of agriculture and food chemistry \\
\hline
\end{tabular}

Table 1. Example of title variety: at the beginning of the analysis the title "Journal of agricultural and food chemistry” appeared in 20 different versions.

A librarian can cope with such variations, but software cannot. The initial list of 49,886 titles was refined through both an "ad-hoc" software tool and eventually by manual intervention of the authors. The software tool used to standardize titles uses PHP5 and MySQL and comprises two procedures: title pre-processing and title consistency. The latter searches the database and overwrites each title in standard form. The pre-processing tool receives a csv (comma-separated values) file input and generates a new UTF8-XML file as output. Data in the csv file must be arranged in two columns, each row containing two values: an "alias", which can be represented as an ISSN, eSSN, or a title abbreviation, and a "name" which contains the standard form of the title.

Several sources were used to standardize titles: three lists of serials from Thomson Reuters web site containing ISSN and full journal titles (Science Citation index, Social Science Citation Index and Arts and Humanities Citation Index journals) [4]; the American Chemical Society CAplus ${ }^{\mathrm{SM}}$ Core Journal Coverage List containing journal abbreviations and their full titles [5]; a list of full journal titles, containing ISSN, eSSN, and NLM journal abbreviations from the National Library of Medicine web site [6]. Unfortunately, the proportion of ILL requests having an ISSN was low thus standardization of titles based on ISSN was inadequate. After several cycles of running the title standardisation tool, final manual interventions assessed the number of unique journal titles at 23,810. There were 3,741 requests for monograph parts (earth sciences and physics were the most requested), which was less than $1 \%$ of all ILL transactions.

ILL data transactions were then analyzed using MySQL queries against the Whnilde database. Summary data were later exported from MySQL and imported into Excel for the authors to elaborate, study, format, and present. Statistical analysis was performed using SPSS 18.0 (SPSS Inc, Chicago, IL).

\section{Results and discussion}

The aim of this study is to present a quantitative and qualitative analysis of journal titles shared by Italian libraries through their ILL service. There are few Italian studies on the subject, and this is the most extensive in terms of libraries involved and ILL requests examined. 
Results from ILL article sharing among NILDE libraries, over the five year period 2005-2009, show an overall rise in ILL activities.

\section{Total NILDE requests and network use}

Table 2 shows the number of borrowing libraries, the total number of requests, filled and unfilled, the average number of filled requests per library and the number of journal titles used in each year of the study. We can see an upward trend in all of them.

\begin{tabular}{lccccc}
\hline & 2005 & 2006 & 2007 & 2008 & 2009 \\
\hline Borrowing Libraries & 496 & 520 & 558 & 602 & 633 \\
Total requests & 86,320 & 100,643 & 113,250 & 121,212 & 137,065 \\
Filled requests & 75,652 & 87,846 & 99,083 & 106,908 & 121,925 \\
Unfilled Requests & $10,668(12.4 \%)$ & $12,797(12.7 \%)$ & $14,167(12.5 \%)$ & $14,304(11.8 \%)$ & $15,140(11.0 \%)$ \\
Average number of filled & 153 & 169 & 178 & 178 & 193 \\
requests/library & 6287 & 6962 & 7823 & 7960 & 8471 \\
Unique journal titles & 6 & &
\end{tabular}

Table 2: NILDE network document supply data over the five-year period 2005-2009

This growth could be explained by the net increase in the number of libraries joining the network.

The NILDE network is continuously changing, due to the large number of libraries joining and some of them leaving in a given year. The number of libraries joining has been constantly growing. These elements of flexibility also suggest a more careful approach in evaluating the growth of ILL requests, since data sets may be affected by such a continuously changing framework. However, the $26 \%$ increase in the average number of requests per library indicates a real increase in ILL activity across Italian libraries. This is in line with the ARL experience.

To understand whether ILL growth may be attributed to some specific group of libraries, Figure 1 shows ILL requests grouped by the borrower's disciplinary fields.

\section{Insert Figure 1 here}

Figure 1 shows that increases occurred in all disciplines but Biomedicine and S\&T libraries dominate in terms of volume and are responsible, respectively, for more than $50 \%$ and $30 \%$ of all transactions.

\section{Journal title use}

Table 2 also shows a remarkable growth in unique journal titles year by year, showing a greater diversification in end-user needs to support their research. Figure 2 illustrates the distribution of title use. $30 \%(7,187)$ of titles were requested only once over the five-year period by all the NILDE libraries. $60 \%(14,322)$ of titles were requested no more than five times, thus on average less than once a year. Only 5\% (1206) of titles were requested more than 100 times, thus on average more than 20 times a year and they account for $53 \%$ of all transactions. These findings are in agreement with previous studies, (Wiley and Chrzastowski, 2005), (Lacroix and Collins, 2007), (Tonta and Ünal, 2005), (Tutiya et al, 2007), and demonstrate that requests are spread over many titles and only a small number are heavily used for ILL.

\section{Insert Figure 2 here}

\section{Date distribution of requests}

Figure 3 shows the requests distribution by publication date. We note that the graph curves for older documents are similar and these results are consistent with previous studies, (Lacroix, 1994; 
Lacroix and Collins, 2007). However, it also shows that the number of requests for articles published in the most recent years is high and increasing year by year demonstrating that researchers require an even higher proportion of the most recently published material than previously was the case. In fact, requests for articles published in the same year as the request rose from $11.9 \%$ to $14.9 \%$ during the period of the research.

\section{Insert Figure 3 here}

Figures $4 \mathrm{a}-4 \mathrm{e}$ represent the date distribution of requests in another way: requests are grouped in time-ranges, (as in Echeverria and Barredo, 2005), in order to highlight possible trends in requests for recently published and older articles.

\section{Insert Figures 4a', 4a’'-..- 4e',4e'” here}

Figures 4a', 4b', 4c', 4d', 4e', are very similar year by year and reveal no trend. The left-hand column(s) show the percentage of requests for articles published in the most recent three years; they indicate a slight rise from 32\% (2005) to 34\% (2009): this figure agrees with those of Russon and Murdoch (Russon, 2001; Murdoch, 2001) who found that, depending on the disciplinary field, between $20 \%$ and $50 \%$ of requests were for articles published within the last three years. The righthand column(s) showing material published more than 22 years ago also shows a rising trend from $13 \%$ (2005) to $18 \%$ (2009). However, it is only an apparent growth, brought about by the shift forward of data each year (that is, the percentage of requests for articles published up to 1982, in each year from 2005 to 2009 , does not change).

Pie charts in figures 4a', 4b', 4c', 4d"', 4e', provide further insight into the publication date distribution of requests within the last three years, showing that current publications are increasingly involved in document supply.

Since most Italian universities and research institutions have been accessing many multidisciplinary collections purchased through library consortia in the form of Big Deals or disciplinary journal packages and are, at the same time, responsible for a large number of ILL requests, our findings demonstrate, at least for Italy, an increasing request for recently published documents probably not belonging to big publishers.

The following part of the study focuses upon the most requested journals, through quantitative and qualitative analysis, in order to clarify what users mainly request and why their requests are increasing.

\section{Most requested journals}

From here onwards, we narrow our analysis to requests for articles published within the previous five years, for several reasons:

- $\quad$ more than $80 \%$ of requests come from S\&T and biomedical users, interested in reading and citing recent literature;

- $\quad$ since our request data range between 2005 and 2009, taking into account only requests for articles published within the previous five years implies a range of publication years between 2000 and 2009 - that is, a time period equally affected by Big Deal licenses;

- $\quad$ older publications, at least in the S\&T and biomedical fields, do not affect decisions on subscriptions;

- $\quad$ the data interval is large enough to highlight possible trends.

Table 3 shows the top 10 requested titles in each year and some interesting information emerges. 


\begin{tabular}{|c|c|}
\hline \multicolumn{2}{|r|}{2005} \\
\hline Requests & Journal Titles \\
\hline 240 & Annals of The New York Academy of Sciences \\
\hline 152 & Oncogene \\
\hline 146 & Anticancer Research \\
\hline 129 & Archives of Internal Medicine (1960) \\
\hline 115 & Hepato-Gastroenterology \\
\hline 109 & Journal of Pediatric Endocrinology \& Metabolism \\
\hline 105 & Current Pharmaceutical Design \\
\hline 98 & Current Medicinal Chemistry \\
\hline 93 & British Journal of Cancer \\
\hline 84 & International Journal of Oncology \\
\hline \multicolumn{2}{|r|}{2006} \\
\hline Requests & Journal Titles \\
\hline 397 & Annals of The New York Academy of Sciences \\
\hline 146 & Anticancer Research \\
\hline 133 & Current Pharmaceutical Design \\
\hline 104 & Current Medicinal Chemistry \\
\hline 96 & Methods In Molecular Biology \\
\hline 94 & Kidney International \\
\hline 91 & Hepato-Gastroenterology \\
\hline 87 & Radiation Protection Dosimetry \\
\hline 85 & Journal of Food Protection \\
\hline 82 & Journal of Endocrinological Investigation \\
\hline \multicolumn{2}{|r|}{2007} \\
\hline Requests & Journal Titles \\
\hline 286 & Annals of The New York Academy of Sciences \\
\hline 198 & Anticancer Research \\
\hline 162 & Current Medicinal Chemistry \\
\hline 151 & Current Pharmaceutical Design \\
\hline 140 & Methods In Molecular Biology \\
\hline 122 & Expert Opinion on Pharmacotherapy \\
\hline 111 & Progress In Brain Research \\
\hline 104 & Drugs \\
\hline 104 & Journal of Pediatric Endocrinology \& Metabolism \\
\hline 102 & Hepato-Gastroenterology \\
\hline \multicolumn{2}{|r|}{2008} \\
\hline Requests & Journal Titles \\
\hline 226 & Current Medicinal Chemistry \\
\hline 181 & Expert Opinion on Pharmacotherapy \\
\hline 173 & Circulation \\
\hline 172 & Current Pharmaceutical Design \\
\hline 168 & Anticancer Research \\
\hline 167 & Nature Protocols \\
\hline 150 & Proceedings of The National Academy of Sciences of The United States of America \\
\hline 134 & Oncogene \\
\hline 128 & Journal of Clinical Oncology \\
\hline 125 & Chest \\
\hline \multicolumn{2}{|r|}{2009} \\
\hline Requests & Journal Titles \\
\hline 253 & Current Pharmaceutical Design \\
\hline 246 & Frontiers In Bioscience \\
\hline 225 & Current Medicinal Chemistry \\
\hline 206 & Anticancer Research \\
\hline 201 & Expert Opinion on Pharmacotherapy \\
\hline
\end{tabular}

To be published in Interlending \& Document Supply v. 39(1), 2011, Emerald Group Publishing Limited All rights reserved. 


\begin{tabular}{|l|l|}
179 & Progress In Brain Research \\
\hline 173 & Methods In Molecular Biology \\
\hline 172 & Nature Protocols \\
\hline 169 & Science (Washington, D.C.) \\
\hline 168 & Journal of Endocrinological Investigation \\
\hline
\end{tabular}

\section{Table 3: Most frequently requested titles}

In 2008 the top title, "Annals of the New York Academy of Sciences", suddenly disappeared. Access to the full-text through the Wiley-Blackwell consortia subscription is the most plausible and simple explanation. Since university and research institution end-users can quickly download Pdf articles whenever they need them, requests for this journal have fallen dramatically. This is an example of consortia purchasing having a big impact on document supply. As said before, ILL data before 2005 are not available, however what happened to this title could give a hint of what had happened in Italy at the beginning of the Big Deal era and its impact on ILL.

Surprisingly, Science, probably the most widely held journal in Italian S\&T libraries, appears in the 2009 top ten list. In 2008 the Italian National Research Council (CNR), the largest government research institution in Italy, discontinued its subscription to Science Online because of disagreements with the publisher regarding the dramatic increase in the requested subscription price. This caused several CNR libraries to use ILL to satisfy their researchers' needs. It should be noted that Science Online provides free access to research articles one year after publication. Since one of the authors has been directly involved in the exhausting, three-year long, price negotiation with the publisher, we can say that an agreement satisfying both parties has recently been reached and, seemingly, CNR will subscribe again to Science Online from 2011. This case demonstrates the importance of implementing a national resource sharing policy to make sure libraries have access to scientific information and to withstand publisher demands for unreasonable price increases.

\section{Quantitative analysis of the most requested journals}

Table 4 shows the number of unique journal titles borrowed more than 20 times per year and the corresponding number of filled requests.

\begin{tabular}{lccccc}
\hline & $\mathbf{2 0 0 5}$ & $\mathbf{2 0 0 6}$ & $\mathbf{2 0 0 7}$ & $\mathbf{2 0 0 8}$ & $\mathbf{2 0 0 9}$ \\
\hline Titles requested $\geq 20$ times* & $448(7 \%)$ & $523(8 \%)$ & $597(8 \%)$ & $647(8 \%)$ & $781(9 \%)$ \\
$\begin{array}{l}\text { Total requests } \\
\text { corresponding to titles } \\
\text { requested } \geq 20 \text { times** }\end{array}$ & $15,247(20 \%)$ & $18,541(21 \%)$ & $22,308(23 \%)$ & $25,942(24 \%)$ & $33,524(27 \%)$ \\
$\begin{array}{l}\text { Average borrowings/title by } \\
\text { same library }\end{array}$ & 2.0 & 2.0 & 2.1 & 2.1 & 2.2 \\
$\begin{array}{l}\text { Average lendings/title by } \\
\text { same library }\end{array}$ & 6.8 & 7.1 & 8.3 & 8.7 & 8.9 \\
$\begin{array}{l}\text { Average ratio between } \\
\text { \#borrowing and \#lending }\end{array}$ & 2.9 & 3.8 & 4.5 & 4.6 & 4.5 \\
$\begin{array}{l}\text { libraries per title } \\
\text { Average top use of titles per }\end{array}$ & 6.9 & 7.1 & 7.7 & 7.7 & 8.4 \\
$\begin{array}{l}\text { library } \\
\text { Highest use per title range }\end{array}$ & $1-35$ & $2-89$ & $2-38$ & $2-105$ & $2-94$ \\
\hline
\end{tabular}

Table 4: Highly used titles (requested more than 20 times in a year), average and top use per title.

*In round brackets the percentage with respect to the total number of used titles

** In round brackets the percentage with respect to the total number of requests

In this table only requests of articles published within the previous 5 years are taken into account.

A small proportion (7-9\%) of the journals are responsible for a much higher proportion (20-27\%) of all requests. Borrowing libraries made an average 2.0-2.2 requests for each title between 2005 and 
2009. Lending libraries delivered an average of 6.8-8.9 documents for each title. We note that lending libraries have been supplying more and more articles. The average ratio of borrowing libraries to lending libraries for each title is growing too. The number of lending libraries is almost constant (for these sets of titles), while the number of borrowing libraries is growing (data calculated but not shown).

Table 4 also shows the average use of top titles per library (6.9-8.4) and the range of the highest use per title per library, for example in 2005 the most used titles ranged from 1 only to 35 requests. A closer examination of data found that rarely has a journal been heavily requested by the same library. This happened only once over the five-year period. Such exceptions are not representative of library network behaviour, which generally shows great respect for copyright law.

Previously cited studies found that non-subscriber institutions made an average of 2.4 requests per title, (Russon, 2001), (Murdoch, 2001). In order to answer the question "is document supply an alternative to subscription?", Russon states that "reasonably, the vast majority of organizations are using document supply to meet very occasional needs". However, the 2001 survey examined a limited number of titles (28) within a one year period (2000). The present study, which is supported by the analysis of a much broader number of titles and a longer time-scale, bears out the findings of both Russon and Murdoch.

Thus publishers need not be concerned about ILL services threatening subscription revenues. It is also true that without an ILL service, some published articles would never have been read by researchers of non-subscribing institutions. The dissemination of information, even through document supply, is necessary for increasing the citation rate and other bibliometric indicators. Publishers benefit from a minimum level of ILL and they should support it rather than attempt to obstruct it. Since the recession has reduced library budgets, (Baveye, 2010),(Sykes, 2010), we think it is even more unlikely that libraries would purchase a subscription for a journal which is needed only a few times per year.

\section{Qualitative analysis of the most requested journals}

In order to look into the nature of highly requested titles we studied their impact factors (IF), citation counts, subject categories and publishers. Titles requested more than 20 times in each year were identified and constitute a "core" set of 224 journals (1\% of total titles). These core journals account for 55,841 requests ( $11 \%$ of total requests), and we show the top 20 in Table 5 below.

\begin{tabular}{|c|c|c|c|c|c|c|c|c|}
\hline & Journal title & Publisher* & $2005 \S$ & $2006 \S$ & $2007 \S$ & $2008 \S$ & $2009 \S$ & $\begin{array}{c}\text { mean } \\
\text { requests/year }\end{array}$ \\
\hline 1 & Anticancer Research & $\begin{array}{l}\text { Int Inst Anticancer } \\
\text { Research }\end{array}$ & 146 & 146 & 198 & 168 & 206 & 172,8 \\
\hline 2 & Current Medicinal Chemistry & $\begin{array}{l}\text { Bentham Science } \\
\text { Publ Ltd }\end{array}$ & 98 & 104 & 162 & 226 & 225 & 163,0 \\
\hline 3 & $\begin{array}{l}\text { Current Pharmaceutical } \\
\text { Design }\end{array}$ & $\begin{array}{l}\text { Bentham Science } \\
\text { Publ Ltd }\end{array}$ & 105 & 133 & 151 & 172 & 253 & 162,8 \\
\hline 4 & $\begin{array}{l}\text { Expert Opinion on } \\
\text { Pharmacotherapy }\end{array}$ & Informa Healthcare & 32 & 80 & 122 & 181 & 201 & 123,2 \\
\hline 5 & $\begin{array}{l}\text { Methods in Molecular } \\
\text { Biology }\end{array}$ & Springer & 70 & 96 & 140 & 121 & 173 & 120,0 \\
\hline 6 & Hepato-Gastroenterology & $\begin{array}{l}\text { H G E Update } \\
\text { Medical Publishing S } \\
\text { A }\end{array}$ & 115 & 91 & 102 & 115 & 141 & 112,8 \\
\hline 7 & Oncogene & $\begin{array}{l}\text { Nature Publishing } \\
\text { Group }\end{array}$ & 152 & 80 & 99 & 134 & 96 & 112,2 \\
\hline 8 & $\begin{array}{l}\text { Proceedings of the National } \\
\text { Academy of Sciences of the } \\
\text { United States of America }\end{array}$ & Natl Acad Sciences & 53 & 77 & 96 & 150 & 145 & 104,2 \\
\hline 9 & $\begin{array}{l}\text { Journal of Endocrinological } \\
\text { Investigation }\end{array}$ & Editrice Kurtis S R L & 58 & 82 & 98 & 97 & 168 & 100,6 \\
\hline
\end{tabular}




\begin{tabular}{|c|l|l|c|c|c|c|c|c|}
10 & Adis Int Ltd & 46 & 65 & 104 & 110 & 131 & 91,2 \\
\hline 11 & $\begin{array}{l}\text { Advances in Experimental } \\
\text { Medicine and Biology }\end{array}$ & Springer & 72 & 81 & 73 & 107 & 119 & 90,4 \\
\hline 12 & Journal of Clinical Oncology & $\begin{array}{l}\text { Amer Soc Clinical } \\
\text { Oncology }\end{array}$ & 72 & 64 & 64 & 128 & 117 & 89,0 \\
\hline 13 & Neurology & $\begin{array}{l}\text { Lippincott Williams } \\
\text { \& Wilkins }\end{array}$ & 70 & 72 & 70 & 107 & 123 & 88,4 \\
\hline 14 & $\begin{array}{l}\text { The New England Journal of } \\
\text { Medicine }\end{array}$ & $\begin{array}{l}\text { Massachusetts } \\
\text { Medical Soc }\end{array}$ & 52 & 79 & 65 & 117 & 123 & 87,2 \\
\hline 15 & $\begin{array}{l}\text { Journal of Pediatric } \\
\text { Endocrinology \& Metabolism }\end{array}$ & $\begin{array}{l}\text { Freund Publishing } \\
\text { House Ltd }\end{array}$ & 109 & 63 & 104 & 73 & 82 & 86,2 \\
\hline 16 & $\begin{array}{l}\text { The Annals of } \\
\text { Pharmacotherapy }\end{array}$ & $\begin{array}{l}\text { Harvey Whitney } \\
\text { Books Co }\end{array}$ & 48 & 61 & 87 & 98 & 132 & 85,2 \\
\hline 17 & $\begin{array}{l}\text { Science (Washington, D,C,) } \\
\text { Amer Assoc } \\
\text { Advancement }\end{array}$ & 38 & 73 & 45 & 99 & 169 & 84,8 \\
\hline 18 & Leukemia \& Lymphoma & Taylor \& Francis Ltd & 56 & 66 & 69 & 87 & 142 & 84,0 \\
\hline 19 & $\begin{array}{l}\text { European Journal of } \\
\text { Gynaecological Oncology }\end{array}$ & I R O G Canada, Inc \\
\hline 20 & $\begin{array}{l}\text { Journal of Agricultural and } \\
\text { Food Chemistry }\end{array}$ & Amer Chemical Soc & 63 & 80 & 77 & 91 & 105 & 83,2 \\
\hline
\end{tabular}

Table 5: Top 20 titles among core journals.

*Data about publishers refer to the last upgrade of Journal of Citation Reports 2009 (Thomson Reuters), as retrieved on June $16^{\text {th }}, 2010$

$\S$ Filled requests of articles published over the last five years.

Figure 5 shows the impact factor (IF) range distribution of core titles: $4.5 \%$ of titles (10) have no IF, $78.1 \%$ have an IF between 0 and $6,17.4 \%$ have an IF higher than 6.

\section{Insert Figure 5 here}

The average IF is 4.813 , the median is 2.750 . There are 11 titles with an IF between 26.483 and 47.050 which are all published by the Nature Publishing Group, with the exception of The New England Journal of Medicine. If we exclude these titles, the average IF decreases to 3.410 and the median to 2.695 .

The IF is a much criticized index in bibliometrics and it is well known that it is not suitable for comparing journals in different disciplines. An average IF of 4.813 could be a great or a risible value depending on the journal subject. The most requested title in Table 5, Anticancer research, has a 2009 impact factor lower than 1.5. We analyzed the correlation between IF values and ILL requests for core titles. No correlation was found between the frequency of use of 224 core titles measured by the number of ILL requests in 2009 and their 2009 impact factors (Pearson's r=0,090, $\mathrm{p}=0,191)$. Therefore, the null hypothesis that "no relationship exists between the frequency of use of core journal titles and their journal impact factors" is a valid one. This correlation is less than those found in the study by Tonta and Ünal and seems to confirm that journal impact factors cannot be used as reliable indicators to forecast the numbers of ILL requests, (Tonta and Ünal, 2005).

In order to know whether citation counts for core journals could be a more useful indicator to predict ILL requests, Pearson's correlation was calculated for the 2009 ILL requests of core journals and the 2009 total citation counts for articles published over the same period (2004-2009) in the same journals. Citation counts were taken from Web of Science (Thomson Reuters) taking into account all published items indexed in the database (articles, reviews, letters, meeting abstracts, comments and so on...). Titles not indexed in Web of Science even for one year within the period 2004-2009 were excluded. The correlation between citation counts and ILL requests in the same year was rather weak, although statistically significant (Pearson's $r=0,279, p<0,001$ ). This is consistent with the findings of previous studies (Tonta and Ünal, 2005; Schloegl and Gorraiz, 
2006), but the correlation is weaker than the INIST-CNRS study, which was carried out by specifically taking into account only pharmaceutical journals (Bador et al., 2003).

Core title analysis of subject categories shows a wider distribution of journal disciplinary fields.

Thomson Reuters subject categories [7], were used to assign subject categories to core journals. Some journals could belong to many subject categories (for instance, Oncogene has up to four subjects: Biochemistry \& Molecular Biology; Oncology; Cell Biology, Genetics \& Heredity groups). The authors also assigned subject categories to titles not included in Thomson Reuters lists.

Table 6 shows the frequency distribution of core titles per subject category. Apart from a few titles in $\mathrm{S} \& \mathrm{~T}$, biomedical journals dominate.

\begin{tabular}{|c|c|}
\hline Subject area & Number of titles \\
\hline Oncology & 24 \\
\hline Clinical Neurology & 16 \\
\hline Pharmacology \& Pharmacy & 16 \\
\hline Surgery & 15 \\
\hline Biochemistry \& Molecular Biology & 14 \\
\hline Gastroenterology \& Hepatology & 13 \\
\hline Neurosciences & 12 \\
\hline Endocrinology \& Metabolism & 11 \\
\hline Cell Biology & 10 \\
\hline Nutrition \& Dietetics & 9 \\
\hline Biotechnology \& Applied Microbiology & 6 \\
\hline Genetics \& Heredity & 6 \\
\hline Hematology & 6 \\
\hline Immunology & 6 \\
\hline Medicine, General \& Internal & 6 \\
\hline Public, Environmental \& Occupational Health & 6 \\
\hline Radiology, Nuclear Medicine \& Medical Imaging & 6 \\
\hline Veterinary Sciences & 6 \\
\hline Dentistry, Oral Surgery \& Medicine & 5 \\
\hline Infectious Diseases & 5 \\
\hline Biochemical Research Methods & 4 \\
\hline Cardiac \& Cardiovascular Systems & 4 \\
\hline Critical Care Medicine & 4 \\
\hline Food Science \& Technology & 4 \\
\hline Medicine, Research \& Experimental & 4 \\
\hline Pediatrics & 4 \\
\hline Peripheral Vascular Disease & 4 \\
\hline Psychiatry & 4 \\
\hline Rehabilitation & 4 \\
\hline Toxicology & 4 \\
\hline Urology \& Nephrology & 4 \\
\hline Chemistry, Analytical & 3 \\
\hline Chemistry, Medicinal & 3 \\
\hline Chemistry, Multidisciplinary & 3 \\
\hline Chemistry, Organic & 3 \\
\hline Dermatology & 3 \\
\hline Environmental Sciences & 3 \\
\hline Multidisciplinary Sciences & 3 \\
\hline Obstetrics \& Gynecology & 3 \\
\hline Orthopedics & 3 \\
\hline Pathology & 3 \\
\hline Respiratory System & 3 \\
\hline Rheumatology & 3 \\
\hline
\end{tabular}


Allergy 2

Biology 2

Chemistry, Applied 2

Chemistry, Physical 2

Engineering, Biomedical 2

Geriatrics \& Gerontology 2

Materials Science, Multidisciplinary 2

Medical Laboratory Technology 2

Microbiology 2

Physics, Applied 2

Physics, Condensed Matter $\quad 2$

Polymer Science $\quad 2$

Spectroscopy 2

Virology 2

Acoustics 1

Agriculture, Multidisciplinary 1

Anesthesiology 1

Biophysics

Cell \& Tissue Engineering 1

Engineering, Environmental 1

Geosciences, Multidisciplinary 1

Health Care Sciences \& Services $\quad 1$

Instruments \& Instrumentation 1

Materials Science, Biomaterials 1

Meteorology \& Atmospheric Sciences 1

Mycology 1

Nuclear Science \& Technolog 1

Nursing 1

Obstetrics \& Gynecology 1

Ophthalmology 1

Otorhinolaryngology 1

Parasitology 1

Physics, Atomic, Molecular \& Chemical 1

Plant Sciences 1

Psychology 1

Sport Sciences 1

Table 6: Frequency distribution of core titles per subject category

Table 7 shows the frequency distribution of core titles per publisher and the average number of requests per title.

\begin{tabular}{lcc}
\hline \multicolumn{1}{c}{ Publisher } & Number of titles & Average number of requests/title \\
\hline Lippincott Williams \& Wilkins & 20 & 218 \\
Nature Publishing Group & 17 & 239 \\
Wiley & 14 & 223 \\
Taylor \& Francis Ltd & 10 & 251 \\
W B Saunders Co-Elsevier Inc & 10 & 188 \\
Springer & 8 & 265 \\
Thieme & 7 & 224 \\
Adis Int Ltd & 6 & 226 \\
Karger & 6 & 209 \\
Elsevier Science Inc & 4 & 248 \\
Amer Assoc Cancer Research & 3 & 284 \\
Amer Medical Assoc & 3 & 327 \\
Bentham Science Publ Ltd & 3 & 648 \\
Mary Ann Liebert Inc & 3 & 304
\end{tabular}


Oxford Univ Press

Sage Publications

Amer Chemical Soc

Amer Geophysical Union

Amer Inst Physics

Amer Veterinary Medical Assoc

B M J Publishing Group

Cambridge Univ Press

Federation Amer Soc Exp Biol

Informa Healthcare

Iop Publishing Ltd

Quintessence Publishing Co Inc

Royal Soc Chemistry

Spandidos Publ Ltd

Walter De Gruyter \& Co

Academy of Neonatal Nursing

Alphamed Press

Amer Acad Pediatrics

Amer Acad Periodontology

Amer Assoc Advancement Science

Amer Assoc Clin Endocrinol

Amer Assoc Clinical Chemistry

Amer Assoc Immunologists

Amer Assoc Neurological Surgeons

Amer Coll Allergy Asthma Immunology

Amer Coll Chest Physicians

Amer College Nutrition

Amer Diabetes Assoc

Amer Inst Ultrasound Medicine

Amer Occupational Therapy Assoc, Inc

Amer Roentgen Ray Soc

Amer Soc Biochemistry Molecular Biology Inc

Amer Soc Clinical Nutrition

Amer Soc Clinical Oncology

Amer Soc Clinical Pathology

Amer Soc Nephrology

Amer Soc Nutritional Science

Amer Soc Trop Med \& Hygiene

Aoac Int

Biolife Sas

British Veterinary Assoc

Cell Press

Chemical Soc Japan

Clinical \& Exper Rheumatology

Cmp Media LLC

Dustri-Verlag Dr Karl Feistle

Editrice Kurtis S R L

Edizioni Int Srl

Edizioni Minerva Medica

Emap Healthcare

Endocrine Soc

European Respiratory Soc Journals Ltd 


\begin{tabular}{|c|c|c|}
\hline H G E Update Medical Publishing S A & 1 & 564 \\
\hline Harvey Whitney Books Co & 1 & 426 \\
\hline I C R Publishers & 1 & 230 \\
\hline I R O G Canada, Inc & 1 & 416 \\
\hline Il Pensiero Scientifico & 1 & 219 \\
\hline Int Assoc Food Protection & 1 & 392 \\
\hline Int Inst Anticancer Research & 1 & 864 \\
\hline Int Medical Press Ltd & 1 & 247 \\
\hline Ios Press & 1 & 198 \\
\hline J Reprod Med Inc & 1 & 238 \\
\hline J Rheumatol Publ Co & 1 & 401 \\
\hline $\begin{array}{l}\text { Johann Ambrosius Barth Verlag } \\
\text { Medizinverlage Heidelberg Gmbh }\end{array}$ & 1 & 170 \\
\hline Journal Bone Joint Surgery Inc & 1 & 213 \\
\hline Lombardo Editore & 1 & 180 \\
\hline M I T Press & 1 & 175 \\
\hline Maney Publishing & 1 & 215 \\
\hline Massachusetts Medical Soc & 1 & 436 \\
\hline Masson Editeur & 1 & 181 \\
\hline Natl Acad Sciences & 1 & 521 \\
\hline Pharmacotherapy Publications Inc & 1 & 276 \\
\hline Physicians Postgraduate Press & 1 & 389 \\
\hline Portland Press Ltd & 1 & 133 \\
\hline Pulsus Group Inc & 1 & 123 \\
\hline Quadrant Healthcom Inc & 1 & 186 \\
\hline Radiation Research Soc & 1 & 221 \\
\hline Routledge Journals, Taylor \& Francis Ltd & 1 & 180 \\
\hline Royal Soc Medicine Press Ltd & 1 & 143 \\
\hline Setac Press & 1 & 243 \\
\hline Soc Applied Spectroscopy & 1 & 137 \\
\hline Soc General Microbiology & 1 & 163 \\
\hline Soc Neuroscience & 1 & 227 \\
\hline Società Editrice Universo & 1 & 184 \\
\hline Southeastern Surgical Congress & 1 & 155 \\
\hline Thomson Reuters (Scientific) Ltd & 1 & 159 \\
\hline Univ Chicago Press & 1 & 354 \\
\hline Vsp Bv & 1 & 160 \\
\hline
\end{tabular}

\section{Table 7: Frequency distribution of core titles per publisher and average number of requests/title (sum of all requests within 2005-2009)}

Notes to Table 7: Publishers are reported as in Journal of Citation Reports 2009 (Thomson Reuters), as retrieved on June $16^{\text {th }}, 2010$. Some publishers, appearing with different names, were grouped together under a single name:

Sage Publications includes Sage Publications Inc and Sage Publications Ltd.

Wiley includes John Wiley \& Sons Inc, John Wiley \& Sons Ltd, Wiley-Blackwell Publishing, Inc, Wiley-Liss, Wiley-V C H Verlag Gmbh

Springer Includes Springer France

Elsevier Science Inc includes Elsevier Science Inc, Excerpta Medica Inc-Elsevier Science, Pergamon-Elsevier Science Ltd and Academic Press Inc Elsevier Science

Thieme includes: Thieme Medical Publ Inc, Georg Thieme Verlag Kg

Taylor\& Francis includes: Taylor \& Francis As, Taylor \& Francis

Matching the core title list with the titles purchased in Italy through Big Deal consortia, we observed that: only two titles belonging to Springer have been accessible through a Big Deal subscription since 2005; only one title belonging to Elsevier has been available through the Freedom collection since 2008. Wiley requires specific considerations; almost all their titles within the core list are biomedical journals and have been available through Big Deal consortia 
subscriptions. However, these journals are available to almost all university libraries, but not to all health science libraries (mainly health research institutions). A personal communication to the authors stated that a group of health research libraries is now negotiating a new contract to access the Wiley collection through subscription.

The majority of titles in the core are published by small publishing houses or scientific societies. Since these titles are rarely subscribed to through consortia packages, it is almost certain that a tail of demand for these titles will continue in the future. As library budgets are facing large cuts leading to serials cancellations and cost constraints, (Baveye, 2010); (Sykes, 2010) this tail is likely to become increasingly important. Russon's foresights are still enlightening: "An essential issue is that when the core (... Russon was referring to Big Deal licenses) is gone, there is still a social and public policy need to make sure smaller organisations in the public or private sector have access to material published by learned society which is occasionally needed" (Russon, 2001).

\section{Copyright versus contract}

Libraries should pay increasing attention to the licenses for access to electronic resources (databases, e-journals and e-books). Technology has made the ILL process even easier, while digital content licensing often attempts to reverse the speed of service and anachronistically increase costs of paper, toner, shipping and so on, if not to stifle it completely. The greater challenge of the restrictions imposed through electronic licenses could strongly limit the importance and institutional practice of ILL services. In fact, ILL uses for e-journals are usually permitted under certain conditions which can refer, for example, to which type of requests may be processed, how they should be processed and how the requested copies may be delivered (unfortunately, many licensors do not allow ILL at all for the majority of e-book collections).

To this end, Vezzoso underlines the importance of libraries not conceding some of their rights which are recognized by copyright law: "A not only theoretical possibility, therefore, is that the contractual agreements on access to electronic works set aside copyright exceptions. Indeed, some view copyright limitations as default rules (not as imperative rules), to be applied when the producers, intermediaries and end users do not determine directly the conditions of use of protected material. Others fear, however, that without appropriate contractual boundaries, users may be forced to forego some of the privileges recognized by law, in order to gain access to protected material. Of course, it can be argued that at least some copyright restrictions are not merely default rules, and the question would then be if those based on the policy goal of promoting study and research should possibly qualify for any kind of special treatment. ..... In any case, due to the lack of consensus on this rather difficult legal issue, it probably makes more sense to approach the problem pre-emptively by carefully negotiating ILL clauses in licenses for electronic works. For libraries, of course, this can be made individually or through their consortia.”, (Vezzoso, 2006).

A 2003 survey by 13 large research libraries in the Midwest of the USA on how licensing affects both the lending and borrowing operations found that negotiations can often be very effective, even though it takes time to change. With the help of libraries and library associations, publisher restrictions may gradually loosen to allow more ILL use, (Wiley, 2004).

In Italy significant progress has been made in this direction. Since 2005 within the NILDE network a working group has been created to examine the licenses on electronic journals in Italy. The purpose of the group is to foster communication between libraries and consortia and to stimulate them to be more aware about ILL clauses in electronic resource licenses (Zaetta, 2006). A database to collect ILL clauses in electronic licenses has been created [8] and continually updated and, more importantly, the NILDE system has been recognised by some publishers as a secure electronic system to supply a single paper copy or an electronic copy of (individual documents from) their licensed material. The Italian experience has proved that careful negotiation can lead to suitable licensing conditions (Ortigari 2008). 


\section{Conclusions}

The purpose of this article was to provide insights into the relationship between ILL/ document supply and journal subscriptions.

The first question answered is "Does ILL affect electronic or print journal subscriptions?".

The results of this survey of 633 Italian academic and research libraries between 2005 and 2009 show that requests are generally spread over many titles and only a relatively small number of journals $(5 \%)$ are heavily used. NILDE libraries borrow $65 \%$ of articles published more than 2 years earlier, which have no effect on renewals or new subscriptions, making, on average, 2.2 requests per title per year, and each individual title is requested by many libraries.

The primary conclusion from this analysis of national journal resource sharing is that publishers need not be concerned about ILL services, since these are not being used as a surrogate for journal subscriptions. On the contrary, analysis of transaction data often has a positive effect on new title acquisitions and negotiations with publishers. The results of this paper show that publishers should support ILL in their electronic licenses, rather than attempt to obstruct it, since ILL guarantees diffusion of their published works to researchers in non-subscribing institutions.

Answering the question "Do electronic journal subscriptions affect ILL?" is more complex, since various simultaneous effects come into play. An apparently steady or growing trend can hide a more complex situation, such as a shift in demand, due to a number of factors: on one hand greater accessibility through Big Deals, digital conversion of back files and open archives can lead to a decrease, but on the other hand, increased findability and discoverability through databases and internet research engines, increases in end-user populations, changing behaviours and rising expectations due to the ease of access to ILL services, improved turn-around time and the advent of an efficient cooperative network of libraries as with NILDE all have a positive effect on ILL.

The ILL service can be affected by electronic subscriptions only when access becomes available at many institutions simultaneously, as with consortium contracts and/or Big Deals. We foresee a decline in document requests from journals included in new consortia subscriptions and conversely an increase in them with the cancellation of existing contracts.

However, some interesting observations can be drawn from this study. The 2005-2009 results show an overall growth of ILL, in spite of widespread consolidated availability of e-journals acquired through consortia purchasing. More than $80 \%$ of document exchanges are initiated by biomedical and S\&T libraries, which are interested in up-to-date publications. The analysis of publication date distributions of requests shows that very recent publications seem to be increasingly involved in document supply. This finding is in contrast with many other recent studies, reporting that requests for recently published articles are declining, while borrowings for older documents is increasing.

We have studied the most requested journals over the five-year period 2005-2009 with the aim of identifying a core journal collection, that is, the most highly requested journals over the whole period. We have identified a core title collection of 224 journals and examined their impact factors, citations, subject categories and publishers. We found that apart from a few S\&T titles, biomedical journals prevail. There is no correlation between IF and document supply, while citation counts are weakly correlated with ILL requests of highly used titles. The majority of titles in the core are published by small publishing houses or scientific societies.

The existence of a core collection highlights a nationwide demand for these journals which probably should be maintained nationwide, with perhaps more than one copy over several libraries. These are the titles which would be most beneficial to provide access through a consortia project, preferably in electronic format. Since small publishing houses and scientific society journals are rarely acquired through consortia, it is almost certain that a tail of ILL demand for these titles will persist and become more important.

The increase in ILL requests, mainly due to more recent publications (as shown in figure 3), leads us to suggest that this could be the first visible effect of the current economic crisis which involves not only Italian libraries. This suggestion requires further investigation to be verified, but we can 
not exclude that some institutions in economic difficulties have given up subscribing to new titles or have even cancelled subscriptions to less frequently used resources, thus compensating for local needs through borrowing. The economic crisis is likely to bring about cancellations of current subscriptions and to prevent new title acquisitions, resulting in a narrowing of national journal holdings. It is no surprise that some new emerging titles belong to the core too.

This paper sets the bar for further investigation: we need to continue monitoring the situation of title subscriptions in Italy, mapping the national distribution of collections and suggesting journal acquisition priorities for libraries and for consortia. A thorough understanding of what is not available in Italy, but required by users and has to be found abroad, would be useful to develop a more efficient policy of acquisitions at a national level. A nationwide policy to make sure that holding libraries maintain the most requested journals is necessary. Cooperative efforts should be set up to guarantee the distribution of new title acquisitions over many organizations, to avoid the impoverishment/flattening of journal collections and to preserve access to material published by scientific societies and small publishers.

\section{Acknowledgements}

This study could not have been carried out without the support and assistance provided by Diego Malipiero and Alessandro Tugnoli, members of the NILDE development team at the CNR Bologna Research Area Library. The authors would like to acknowledge them particularly for their efforts in the development of the data warehouse and the software used for ILL title control and data analysis. The authors also wish to thank Annalisa Corno, who has provided invaluable information about the titles in the core list which are included in Italian consortia acquisition packages, and Jessica Palmieri and Derek Jones for help in revising the English version of this paper.

\section{Web references}

[1]ARL statistics are available at http://www.arl.org/stats/annualsurveys/arlstats/index.shtml (retrieved October 2010).

[2] NILDE web site is available at http://nilde.bo.cnr.it

[3] NILDE Rule and Regulations are available at http://nilde.bo.cnr.it/index.php?st=11

(retrieved October 2010).

[4] lists of serials from Thomson Reuters web site containing ISSN and full journal titles: http://science.thomsonreuters.com/mjl/ (retrieved April 2010);

[5] list of full journal titles from the National Library of Medicine web site, containing ISSN, eSSN, and NLM journal abbreviations: ftp://ftp.ncbi.nih.gov/pubmed/J Entrez.txt (retrieved April 2010);

[6] the American Chemical Society CAplus ${ }^{\text {SM }}$ Core Journal Coverage List, containing journal abbreviations and their full titles: http://www.cas.org/expertise/cascontent/caplus/corejournals.html (retrieved April 2010).

[7] Thomson Reuters web site used to assign subject categories to core journals:

http://scientific.thomsonreuters.com/cgi-bin/jrnlst/jlsubcatg.cgi? $\mathrm{PC}=\mathrm{D}$

http://science.thomsonreuters.com/cgi-bin/jrnlst/jlsubcatg.cgi? $\mathrm{PC}=\mathrm{SS}$

http://www.thomsonscientific.com/cgi-bin/jrnlst/jlsubcatg.cgi? $\mathrm{PC}=\mathrm{H}$

(all retrieved June 2010)

[8] NILDE Help-licenses database is available at http://nilde.bo.cnr.it/index.php?st=105

(retrieved October 2010).

\section{References}

Bador, P., Romdhane, M. B. and Lafouge, T. (2003), "European pharmaceutical journals: Relationship between demand and indexation - The example of the main French document 
supplier", Canadian Journal of Information and Library Science, Vol 27 No 2, pp 33-55.

Baveye, P. C. (2010), "Sticker Shock and Looming Tsunami : The high cost of academic serials in perspective", Journal of Scholarly Publishing, Vol 41 No 2, pp 191-215.

Echeverria, M. and Barredo, P. (2005), "Online journals: their impact on document delivery", Interlending \& Document Supply, Vol 33 No3, pp 145-149.

Filippucci, G., Bernardini, E., Mangiaracina, S., Brunetti, F., De Carolis, E., Domina, P., Fasano, M., Fuschini, E., Grazioli, M., Magno, R., Olimpieri, Salamone, P., Stabene, S. (2009), "Strategies and alliances into action to improve national collaboration", in Proceedings of the 11th Interlending and Document Supply IFLA Conference, Strategic Alliances and Partnerships in Interlending and Document Supply, 20-22 October 2009, Hannover, Germany. Available at:

http://www.ilds2009.eu/fileadmin/user_upload/Full text/Elena_Bernardini-1.pdf (accessed 23rd July 2010)

Gillet, J. (2008), "Sharing resources, networking and document delivery: the INIST experience", Interlending \& Document Supply, Vol 36 No 4, pp 196-202.

Glover, S. W., Addison, J., Gleghorn, C., Aalai, E. and Annis, S. (2009), "Interlending and document supply trends in NHS North West health libraries 2003/2004 to 2006/2007", Health Information and Libraries Journal, Vol 26 No1, pp 32-38.

Goodier, R. and Dean, E. (2004), "Changing patterns in interlibrary loan and document supply", Interlending \& Document Supply, Vol 32 No4, pp 206-214.

ICSTI. (1996), "A comparative study of access to journals through subscriptions and document delivery". (No current accessibility identified - all URL links appear to be broken)

Jackson, M. E. (2004), "Will electronic journals eliminate the need for ILL?", Interlending \& Document Supply, Vol 32 No 3, pp 192-193.

Kidd, T. (2003), "Does electronic journal access affect document delivery requests? Some data from Glasgow University Library”, Interlending \& Document Supply, Vol 31 No 4, pp 264269.

Koyama, K., Sato, Y., Tutiya, S. and Takeuchi, H. (2009), "Transformation of the ILL Services Among the Japanese University Libraries in Digital Era: The Results of the Comprehensive Analysis of NACSIS-ILL Transaction Records from 1994 to 2007”, in Proceedings of the 11th Interlending and Document Supply IFLA Conference, Strategic Alliances and Partnerships in Interlending and Document Supply, 20-22 October 2009, Hannover, Germany. Available at: http://www.ilds2009.eu/fileadmin/user upload/Full text/ilds kenjikoyama20091021 paper. pdf (accessed on 4th October 2010)

Lacroix, E. M. (1994), "Interlibrary loan in U.S. health sciences libraries: journal article use", Bulletin of the Medical Library Association, Vol 82 No 4, pp 363-8.

Lacroix, E. M. and Collins, M. E. (2007), "Interlibrary loan in US and Canadian health sciences libraries 2005: update on journal article use", Journal of the Medical Library Association : 
Vol 95 No 2, pp 189-94.

Line, M. B., Guerrero, E. M., Jackson, M. E., Mark, N., Sene, H. and Waaijers, L. (2002), “The future of interlibrary loan and document supply: views and comments", Interlending \& Document Supply, Vol 30 No 2, pp 60-65.

Mangiaracina, S. (2002), "NILDE: a Document Delivery System Supporting Document Exchange via the Internet”, Library Hi Tech News, Vol 19 No 8, pp 39-41.

Mangiaracina S., Beghelli E. (2004), "Il Servizio Document Delivery della Biblioteca di Area del CNR di Bologna. Report 2002-2003", Technical report, 2004 available at http://puma.isti.cnr.it/dfdownload.php?ident=/cnr.bibo/2004-TR-001 (accessed on 4th October 2010)

Mangiaracina, S., Zaetta, M., De Matteis, D., Tugnoli, A., Beghelli, E. and Tenaglia, G. (2008), "NILDE: developing a new generation tool for document delivery in Italy", Interlending \& Document Supply, Vol 36 No 3, pp 167-177.

Murdoch, J. (2001), “Access to journals through subscriptions and document delivery : a study for year 2000", in Ingenta Institute, Assumptions versus reality: user behaviour in sourcing scholarly information, edited proceedings of a meeting held on 25th September 2001 at the Royal Society of London, Ingenta Institute, Oxford, pp 83-95

N. I. S. O., ANSI. (2006), The OpenURL Framework for context-sensitive services : an American national standard, National Information Standards Organization, Bethesda, Md.

Ortigari A. (2008), "Diritti e doveri degli utenti nella negoziazione nazionale: discesa libera o slalom speciale?," in: Proceedings of the V Convegno Internet Document Delivery $e$ Cooperazione Interbibliotecaria. "Tools, best practices \& copyright", 21-23 Maggio 2008, Bolzano. Available at: http://puma.isti.cnr.it/dfdownload.php?ident=/cnr.bibo/2008-B2-005 (accessed on 20th October 2010)

Russon, D. (2001), “The relationship between journal subscriptions and document delivery", in Ingenta Institute, Assumptions versus reality: user behaviour in sourcing scholarly information, edited proceedings of a meeting held on 25th September 2001 at the Royal Society of London, Ingenta Institute, Oxford, pp 7-13

Russon, D. and Campbell, R. (1996), “Access to journals: a joint publisher/librarian analysis", Logos, Vol 7 No 2, pp 178-185.

Schloegl, C. and Gorraiz, J. (2006), "Document delivery as a source for bibliometric analyses: The case of Subito", Journal of Information Science, Vol 32 No 3, pp 223-237.

Senftleben M. (2004), "Copyright, limitations and the Three-Step Test: an analysis of The ThreeStep Test in international and EC Copyright Law, Kluwer Law International, The Hague

Sykes, P. (2010), “'I tell you naught for your comfort': Budgetary prospects for academic libraries over the next few years", Serials, Vol 23 No 1, pp 6-11.

Tonta, Y. A. and Ünal, Y. (2005), "Scatter of journals and literature obsolescence reflected in document delivery requests", Journal of the American Society for Information Science and Technology, Vol 56 No 1, pp 84-94. 
Tutiya, S., Takeuchi, H., Sato, Y. and Itsumura, H. (2007), "ILL/DD in Japan across the turn of the century-Basic findings about NACSIS-ILL from 1994 to 2005”, Progress in Informatics, No 4, pp 29-49.

Vezzoso, S. (2005), "Document delivery e invio elettronico: profili comunitari alla luce del caso 'Subito'”, DANTE - Diritto d'Autore e Nuove Tecnologie, Vol 1 No 1, pp 7-33. Available at http://eprints.biblio.unitn.it/archive/00000916/ (accessed on 23rd July 2010)

Vezzoso, S. (2006), "Subito and Beyond: new challenges for library document delivery in Europe?", paper presented at the IV Conference on Internet Document Delivery and library cooperation, DD services and electronic resources: the user needs, the library answers, 1819 May 2006, Naples, Italy, available at: http://papers.ssrn.com/sol3/papers.cfm?abstract_id=1357322 (accessed on 23rd July 2010)

Wiley, L. and Chrzastowski, T. E. (2001), "The state of ILL in the state of IL: the Illinois Interlibrary Loan Assessment Project", Library Collections Acquisitions \& Technical Services, Vol 25 No 1, pp 5-20.

Wiley, L. N. (2004), "License to Deny? Publisher restrictions on document delivery from e-licensed journals", Interlending \& Document Supply, Vol 32 No 2, pp 94-102.

Wiley, L. and Chrzastowski, T. E. (2005), "The impact of electronic journals on interlibrary lending: A longitudinal study of statewide interlibrary loan article sharing in Illinois", Library Collections Acquisitions \& Technical Services, Vol 29 No 4, pp 364-381.

Woodward, A. M. (1978), "Factors affecting the renewal of periodical subscriptions: a study of decision-making in libraries with special reference to economics and inter-library lending", 0851421083, Aslib, London

Zaetta M. (2006), "Le clausole DD/ILL nelle licenze per le riviste elettroniche in Italia: politiche degli editori a confronto", in Proceedings of the IV Convegno Internet Document Delivery e cooperazione interbibliotecaria "Servizi DD e risorse elettroniche: le esigenze degli utenti, le risposte delle biblioteche" 18-19 Maggio 2006, Napoli. Available at: http://puma.isti.cnr.it/dfdownload.php?ident=/cnr.bibo/2006-B2-015 (accessed on 20th October 2010)

Zaetta M., and Mangiaracina, S. (2008), "Document Delivery e trasmissione elettronica sicura: uno stato dell'arte". Biblioteche oggi, Vol 26 No 2, pp 25-36.

\section{Further reading}

Proceedings of the I-V Italian conferences on Internet Document Delivery and Inter-Library Cooperation (2001 - 2008). Available at:

http://leonardo.isti.cnr.it/metaopac/servlet/Isis?Dsfor $=200 \& O b j=\% 40 \mathrm{cnr}-$ pListtibib r.pft $\% 2$ CSortedBy $\% 3 \mathrm{~A} \% 40 \mathrm{cnrSS}$ r yetyti.pft\&Opt $=$ search $\&$ Field $0=\&$ Field $1=\&$ Field $2=\&$ Field $8=\&$ Field $4=\&$ Field $3=$ B $2 \&$ Field $5=$ BIBO $\&$ Rqar $=\mathrm{y} \&$ Conf $=\% 2$ Fexport $\% 2$ Fho me\%2Fmetaopac\%2Fmpisa \%2FcnrpConf\%2Fcnr bibo-pub-

list.sys.file $\mathrm{x} \& \mathrm{SrcWin}=1 \& \mathrm{Dsfr}=1$

(accessed on 23rd July 2010) 


\section{About the authors}

Dr. Elena Bernardini is the Head librarian at the Biblioteca centrale di Farmacia, Università degli Studi di Milano, Italy

elena.bernardini@unimi.it

Via Balzaretti, 9 - 20133 Milano

Tel +39-02-50318425

Fax +39-02-50318421

Dr. Silvana Mangiaracina is the Head librarian at the Biblioteca dell'Area di Ricerca di Bologna, Consiglio Nazionale delle Ricerche, Italy.

mangiaracina@area.bo.cnr.it

Via Gobetti, 101 - 40129 Bologna

Tel. +39-051-6398026

Fax +39-051-6398130 


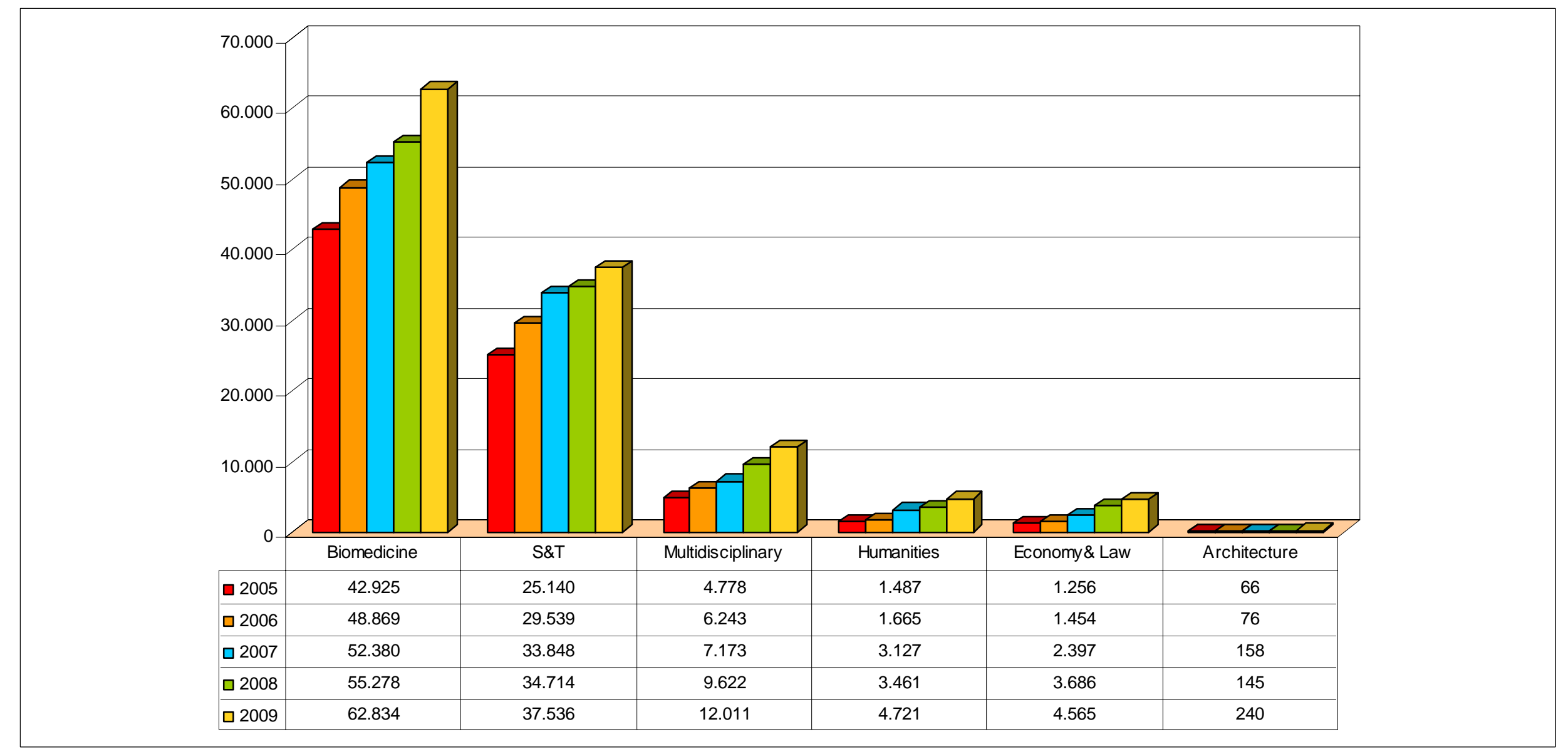

Figure 1: Filled requests per library disciplinary field over the five year period 2005-2009.

To be published in Interlending \& Document Supply V. 39 (1), 2011. Emerald Group Publishing Limited. All rights reserved 


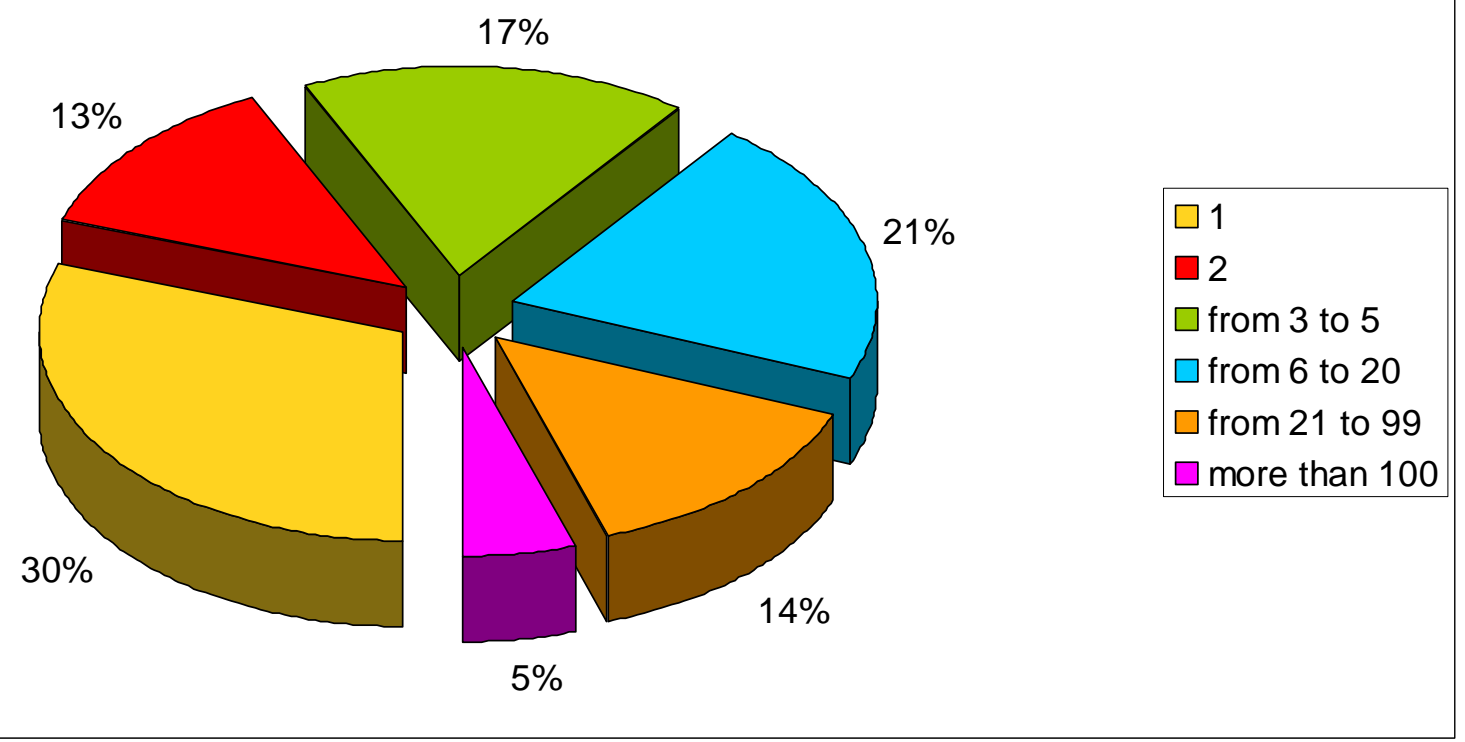

Figure 2: Percentage of filled request per title over the five year period 2005-2009.

To be published in Interlending \& Document Supply V. 39 (1), 2011. Emerald Group Publishing Limited. All rights reserved 


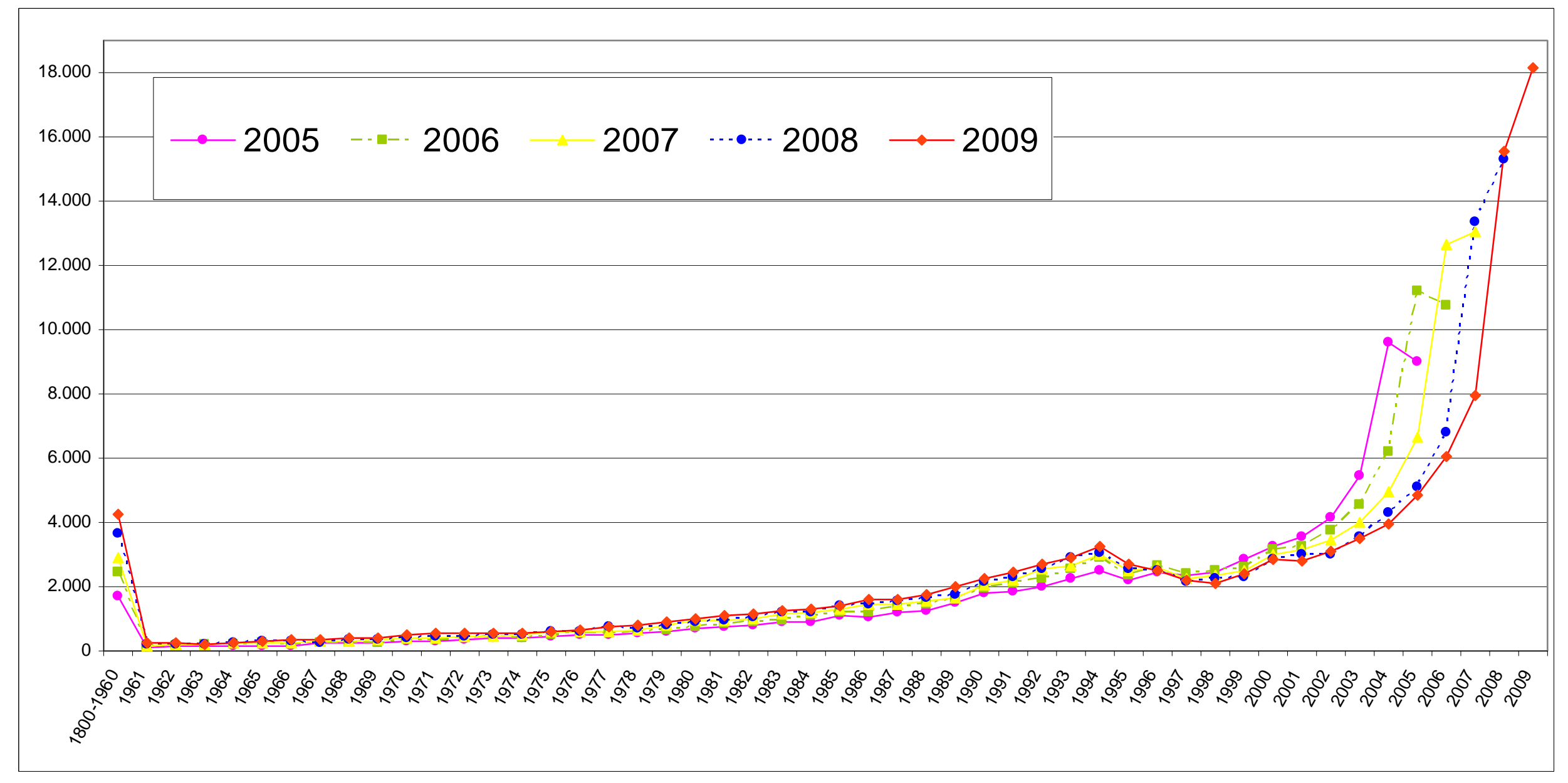

Figure 3: Requests distribution per publication date. 

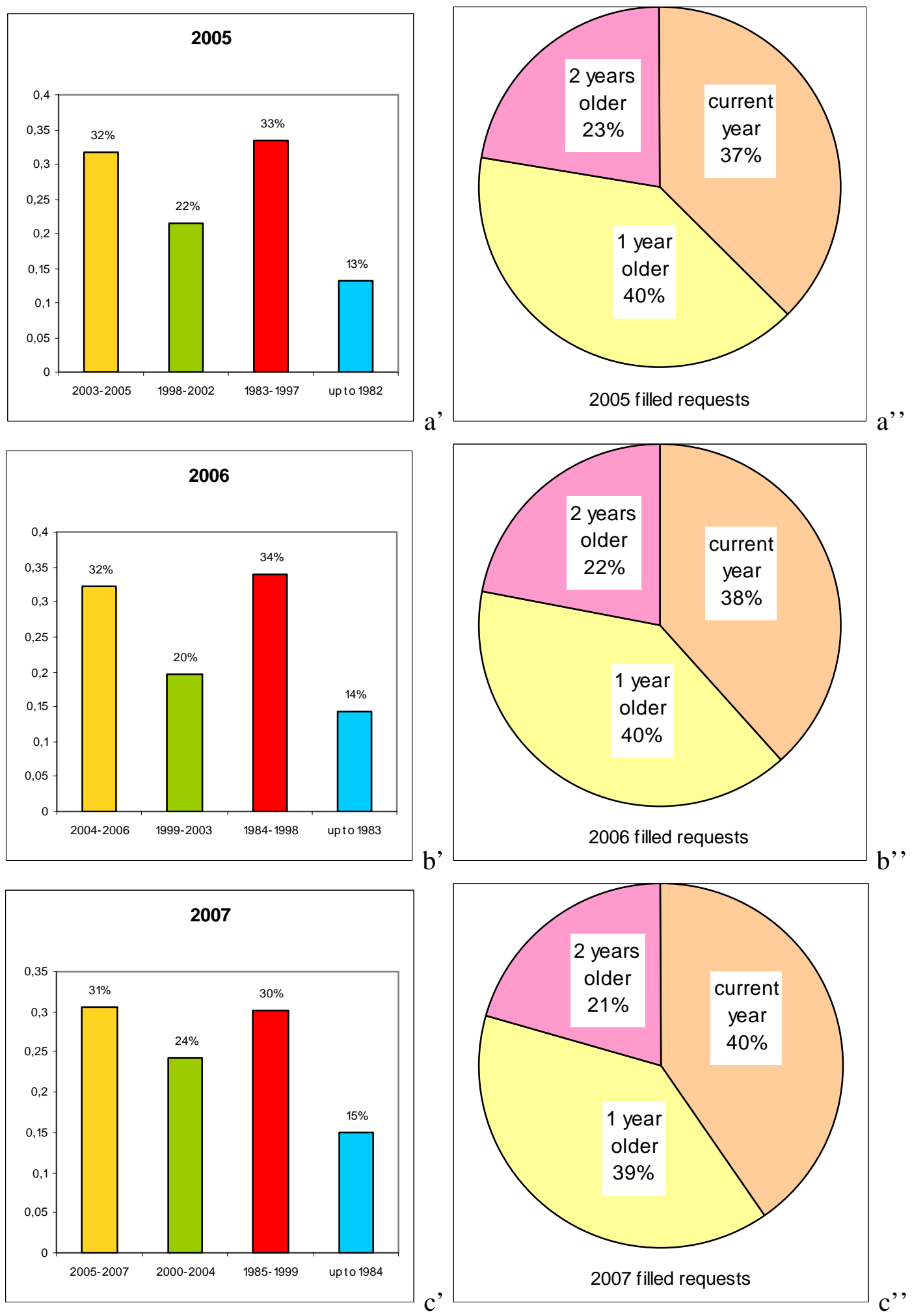

To be published in Interlending \& Document Supply V. 39 (1), 2011. Emerald Group Publishing Limited. All rights reserved 

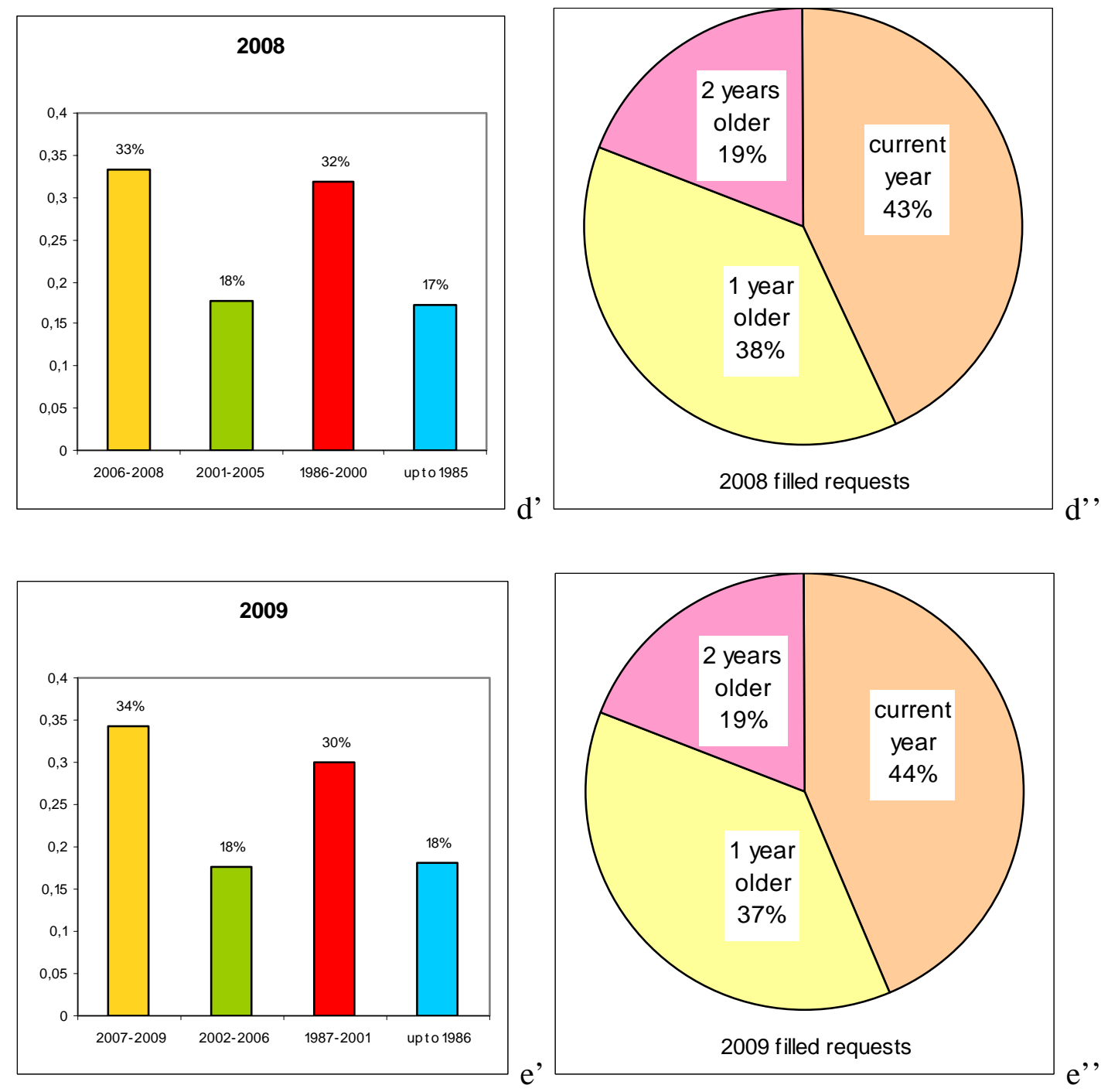

Figures 4a-4e: Requests per publication date grouped in time-ranges.

To be published in Interlending \& Document Supply V. 39 (1), 2011. Emerald Group Publishing Limited. All rights reserved 


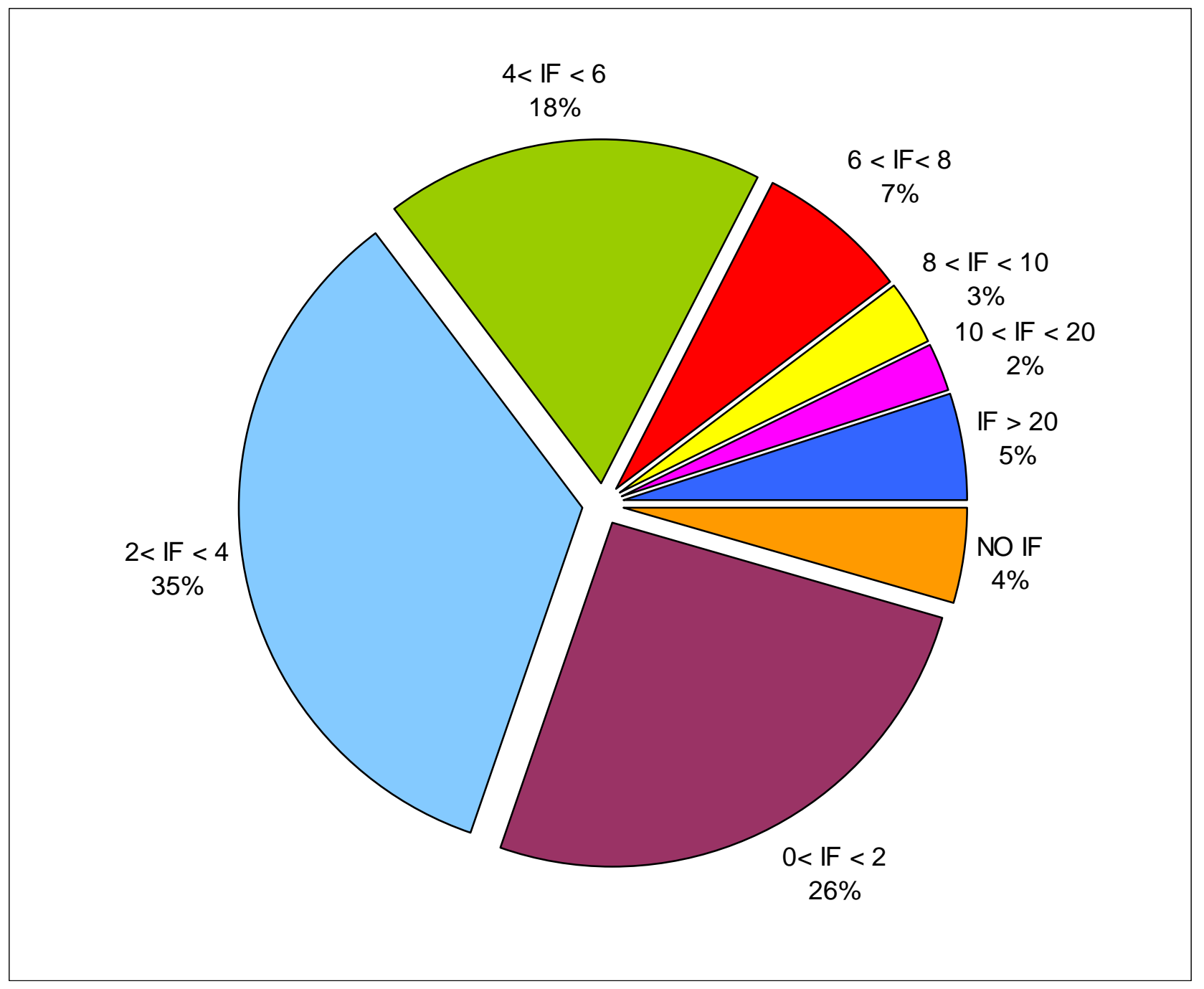

Figure 5. Core titles distribution per Impact Factor

To be published in Interlending \& Document Supply V. 39 (1), 2011. Emerald Group Publishing Limited. All rights reserved 